\title{
Assessment of the Dietary and Biological Value of a Plant-based Milk Analogue from Fenugreek Seeds
}

\author{
Nataliia Prytulska ${ }^{1}$, Iuliia Motuzka ${ }^{1}$, Anna Koshelnyk ${ }^{1, ~}$, Olena Motuzka ${ }^{2}$ \\ ${ }^{1}$ Department of Commodity Science, Safety and Quality Management, Faculty of Trade and Marketing, Kyiv National University of Trade and \\ Economics, Kyiv, Ukraine \\ ${ }^{2}$ Department of Economics and Management of Foreign Economic Affairs, National Academy of Statistics, Accounting and Audit, Kyiv, \\ Ukraine
}

Email address:

5984242@ukr.net (N. Prytulska), unmot@ukr.net (I. Motuzka), a_koshelnyk@ukr.net (A. Koshelnyk), olmotuzka@gmail.com (O. Motuzka) ${ }^{*}$ Corresponding author

\section{To cite this article:}

Nataliia Prytulska, Iuliia Motuzka, Anna Koshelnyk, Olena Motuzka. Assessment of the Dietary and Biological Value of a Plant-based Milk Analogue from Fenugreek Seeds. International Journal of Food Science and Biotechnology. Vol. 5, No. 3, 2020, pp. 31-38.

doi: $10.11648 /$ j.jifsb.20200503.11

Received: September 17, 2020; Accepted: September 28, 2020; Published: October 7, 2020

\begin{abstract}
The biological and dietary value of the plant-based milk analogue from fenugreek seeds is investigated. The amino acid composition is determined by liquid-column ion exchange chromatography. The completion of protein is tested by its comparison with the amino acid composition of the reference protein, determined by the recommendations of the FAO/WHO expert committee. The amino acid score and the biological value is determined by the computation method. It is found that the plant-based milk analogue from fenugreek seeds contains a significant quantity of essential amino acids, with the largest share of leucine and valine. Glutamic acid, aspartic acid and arginine occupy the largest share among the non-essential amino acids in the plant-based milk analogue from fenugreek seeds. The biological value of proteins in the milk analogue from fenugreek seeds makes $96 \%$, having the high compliance with the biological value of a soya drink (96.4\%). This is positive, because soy is considered to be the closest in protein content and amino acid composition to traditional milk proteins. Therefore, the derived data confirm that fenugreek seeds are applicable as a plant-based source of protein for the expansion of the assortment of food products made of fenugreek seeds, both in the mass-scale consumption and for persons with special needs (in particular the patients with sugar diabetes and intolerance of milk protein).
\end{abstract}

Keywords: Fenugreek Seeds, Plant-based Milk Analogue, Amino Acid, Protein, Biological Value, Amino Acid Score, Dietary Value

\section{Introduction}

Shortage of protein foods in the human diet is a distinctive feature of the latest time, resulting in the increasing occurrences of protein energy failures [1]. This causes the growing number of various deceases related with protein deficit, such as the depressed function of pituitary-adrenal system, weakened processes of decrease of the function of thyroid gland, metabolic failures, slowing of child's grow etc. $[2,3]$. At the same time, products of animal origin tend to be substituted with their plant-based analogues with as high protein quantity and protein assimilability characteristics as in the traditional foods. There are some factors that cause the need to exclude animal proteins from the human diet, such as intolerance of lactose and milk [4]. According to the WHO, nearly $75 \%$ of the global population has lactose intolerance with varying degrees of severity. This pathology occurs mostly in counties of Asia, Africa ( $90 \%$ of the population), South Europe (70\%), and South America. In EU, the occurrence of lactose intolerance varies from 4 to $65 \%$, depending on a country. In the U.S., the rate of decease reaches $25 \%$. In Ukraine, according to various researches, lactose intolerance has been diagnosed in nearly $16 \%$ of the population [5].

According to data from the World Organization of Allergists, milk allergy is the most common cause of allergies in children. In EU countries, allergic reactions on cow milk 
proteins are recorded in 2 to $7.5 \%$ of the persons, making from 10 to $19 \%$ occurrences of anaphylaxis caused by food products [6].

It needs to be mentioned that in the body of humans that have to exclude animal-based food products from the diet, especially milk and dairy products, shortage of protein and other biologically important substances often occur, which may result to functional failures in certain organs and systems. The body can be supplied by the necessary nutrients by consuming food products with the chemical composition best compliant with the cow milk and dairy products. This led to the expansion of production of new foods by using plant-based inputs as the source of protein and other nutritional substances, including plant-based milk analogues [7-9].

The search for plant-based sources for complete protein for making new food products, plant-based milk in particular, has become a vital problem of today. Effective inputs for this purpose can be fenugreek seeds that have rich chemical composition and insulinotropic, antidiabetic, hypocholesterolemic, antitumor, fungicidal, antimicrobial, antioxidant effects for the human body; its stimulates synthesis of hormones, protects organs of gastrointestinal tract etc. [9]. There is research-based evidence that consumption of food products and dietary supplements made of fenugreek seeds helps reduce the level of sugar and cholesterol in blood, decrease exposures of atherosclerosis, obesity and, consequently, cardiovascular and gastrointestinal decease [10]. The work to develop technology of a milk analogue made of fenugreek seeds has been conducted, with testing the content of protein, including its amino acid composition, and assessment of the product's biological value as its important part.

The article's objective is to test the amino acid composition of milk analogues from fenugreek seeds, and determine the biological value of the protein.

This objective has to be achieved through solving the following set of problems:

1. determine the quantity of amino acids in the milk analogue from fenugreek seeds;

2. calculate the amino acid score of the essential amino acids in the milk analogue from fenugreek seeds;

3. determine the ratio of distinction of the amino acid score and calculate the biological value of protein in the milk analogue from fenugreek seeds;

The research hypothesis is that the milk analogue from fenugreek seeds is applicable as a source of protein with high biological value, both in the mass-scale nutrition of humans and in the nutrition of patients with sugar diabetes and intolerance of milk protein.

\section{Materials and Methods}

The amino acid composition is determined by the method of liquid-column ion exchange chromatography [11, 12] using the computerized analyzer of amino acids AAA 400 manufactured by "Ingos - Laboratory Instruments" company (Czech Republic).

The completion of protein in the milk analogue from fenugreek seeds by its amino acid composition is tested by the comparing it with the amino acid composition of the reference protein, determined by recommendations of the FAO/WHO expert committee. The amino acid score (AAS) and the biological value is determined by the computation method.

The soya-based milk analogue "SOYA ORIGINAL" TM "Alpro" is selected for purposes as the control product.

\subsection{Sample Preparation}

The amino acid composition was determined after the acid hydrolysis was applied for amino acids and alkaline hydrolysis - for tryptophan. The acid hydrolysis was made by the hydrochloric acid in the following way: a carefully weighted sample with inclusion of the water solution of protein with the mass of nearly $2 \mathrm{mg}$ was put on the bottom of a test-tube. The equal amount of the concentrated hydrochloric acid was added to the water solution. After that the test-tube was cooled in a mixture of dry ice and acetone. Then the air was pumped off from the test-tube using a vacuum pump, to prevent oxidation of amino acids in the result of hydrolysis. After that the test-tube was soldered and mounted into a thermostat with the constant temperature $+106^{\circ} \mathrm{C}$ for 24 hours. Once the hydrolysis is finished, the test-tube has to be cooled down to the room temperature and opened; the content has to be taken off and brought to a glass box and put in a vacuum desiccator above the granulated sodium hydroxide. After that the air has to be removed by a water jet pump. The sample is dried, 3 to $4 \mathrm{ml}$ of deionized water is added to a weighting bottle, and the drying procedure is repeated. It is also possible to remove hydrochloric acid on the water bath under an extractor hood. A sample prepared in this way has to be dissolved in 0.3-normal lithium citrate buffer $\mathrm{pH} 2.2$ and put on an ion exchange column of the amino acid analyzer.

Tryptophan can be determined by use of the alkaline hydrolysis, which is not applicable in determining other amino acids, because the alkaline hydrolysis changes a number of amino acids $[13,14]$.

\subsection{Calculation of Qualitative and Quantitative Amino Acids Content}

Prior to calculating the quantity of amino acids in the tested sample, a standard mixture of amino acids with the known concentration of each amino acid has to be put on a computerized analyzer's column. The peak area of each amino acid (or the peak height) is calculated on a chromatograph. The number of micromoles of each amino acid $\left(\mathrm{X}_{1}\right)$ in the test solution can be derived by the formula (1):

$$
\mathrm{X}_{1}=\mathrm{S}_{1} / \mathrm{S}_{\mathrm{o}}
$$

where: $S_{1}$ is the peak area (or height) of an amino acid in the test sample;

$\mathrm{S}_{\mathrm{o}}$ is peak area (or height) of the same amino acid in a solution of a standard amino acids mixture corresponding to 1 micromolar amount of each amino acid.

The quantity in milligrams is obtained by multiplying the number of micromoles in an amino acid by its molecular mass. 
The quantitative composition of amino acids is determined by comparing chromatograms of the standard and test mixture of amino acids $[13,14]$.

\subsection{Determination of Biological Value}

The protein usefulness in the milk analogue from fenugreek seeds by amino acid composition was determined by comparing it with the amino acid composition of the reference protein, determined by the recommendations of the FAO/WHO expert committee. The amino acid score (AAS) of each essential amino acid was computed by the recommendations of the $\mathrm{FAO} / \mathrm{WHO}$ scale adopted for the protein classification, by the formula (2):

$$
\mathrm{AAS}_{\mathrm{j}}=\left(\mathrm{AK}_{\mathrm{j}} / \mathrm{AK}_{\mathrm{c}}\right) \times 100 \%,
$$

where: $\mathrm{AAS}_{\mathrm{j}}$ is the amino acid score of $\mathrm{j}$ amino acid protein, $\%$;

$\mathrm{AK}_{\mathrm{j}}$ is the content of an essential amino acid in $1 \mathrm{~g}$ of the product protein, $\mathrm{mg} / \mathrm{g}$ of protein;

$\mathrm{AKC}$ is the content of an essential amino acid in $1 \mathrm{~g}$ of the reference protein, $\mathrm{mg} / \mathrm{g}$ of the reference protein.

Also, the biological value of the protein component was assessed using the coefficient of amino acid rate difference (CARD, \%) by formula (3) $[15,16]$ :

$$
\mathrm{BV}=100-\mathrm{CARD}
$$

where: $B V$ is the biological value of the protein component of a product, $\%$;

$C A R D$ is the coefficient of amino acid rate difference.

CARD was determined by the formula (4) [15]:

$$
\mathrm{CARD}=\sum \Delta \mathrm{DAAS} / \mathrm{n},
$$

where: $\sum \triangle D A A S$ is the ratio of the amino acid score for each essential amino acid to the smallest amino acid score of the essential amino acid;

$n$ is the number of essential amino acids.

The biological and nutritional value of plant-based milk analogue from fenugreek seeds was determined by the following methods:

lipid content - by extraction-weight method using the Soxhlet apparatus in accordance with [17];

nitrogen and total protein content - by the amount of nitrogen by the Kjeldahl method according to ISO 20483: 2013 [18];

carbohydrate content- by the calculation method for the total amount of sugars [19]:

mass fraction of glucose, galactose, sucrose, fructose - by high performance liquid chromatography according to ISO 22662: 2007 [19];

content of dietary fiber - by the method of Kurshner and Hanek [20];

calorie content - by calculation method according to the formula (5):

$$
a * 4+b * 9+c * 4
$$

where: a - mass fraction of proteins;

b - mass fraction of lipids;

c - mass fraction of carbohydrates.

Numerals 4, 9, 4 indicate the amount of energy generated by the combustion of 1 gram of proteins, lipids and carbohydrates, respectively.

\section{Results}

Results of testing the amino acid composition of the

\begin{tabular}{|c|c|c|}
\hline Amino acid & Plant-based milk analogue from fenugreek seeds, $\mathrm{g} / 100 \mathrm{~g}$ of product & Control, g/100g of product \\
\hline \multicolumn{3}{|c|}{ Essential amino acids } \\
\hline Lysine & 0,26 & 0,31 \\
\hline Threonine & 0,30 & 0,22 \\
\hline Methionine & 0,12 & 0,26 \\
\hline Valine & 0,43 & 0,91 \\
\hline Isoleucine & 0,33 & 0,29 \\
\hline Leucine & 0,63 & 0,46 \\
\hline Phenylalanine & 0,29 & 0,36 \\
\hline Tryptophan & 0,02 & 0,04 \\
\hline Total & 2,38 & 2,85 \\
\hline \multicolumn{3}{|c|}{ Non-essential amino acids } \\
\hline Serine & 0,28 & 0,37 \\
\hline Glutamic acid & 0,92 & 1,21 \\
\hline Proline & 0,26 & 0,27 \\
\hline Glycine & 0,20 & 0,23 \\
\hline Cystine & 0,04 & 0,02 \\
\hline Tyrosine & 0,16 & 0,19 \\
\hline Histidine & 0,12 & 0,16 \\
\hline Arginine & 0,64 & 0,60 \\
\hline Asparagine acid & 0,84 & 0,77 \\
\hline Total & 3,74 & 4,05 \\
\hline
\end{tabular}
plant-based milk analogue from fenugreek seeds and the control product are given in Table 1.

Table 1. The amino acid composition of plant-based milk analogue from fenugreek seeds. 
This test of the amino acid composition shows that the plant-based milk analogue from fenugreek seeds contains a considerable number of essential amino acids, in which the largest part is with leucine $(0,63 \mathrm{~g} / 100 \mathrm{~g})$ and valine $(0,43$ $\mathrm{g} / 100 \mathrm{~g})$, which have important biological effects. Leucine helps reduce the level of sugar in blood, which confirms the usefulness of consumption of the plant-based milk analogue from fenugreek seeds by patients with sugar diabetes. Decomposition of leucine in the bone muscles results in creating glutamine and alanine, i. e. amino acids constituting the components with important contributions in maintaining the level of glucose in the body. Also, it ensures the balance of nitrogen required for the process of protein and hydrocarbon metabolism; its prevents the occurrence of tiredness caused by extra generation of serotonin; it is required for building up and normal development of muscle tissues; it protects cells and tissues of muscles from the constant decay; it offers a specific source of energy at cellular level; it is involved in the synthesis of protein; it strengthens the immune system, and stimulates quick would healing [21].

Valine is another key component stimulating growth and synthesis of body tissues. Together with leucine and isoleucine it provides for an energy source in muscle tissues, keeps the level of serotonin, improves the coordination of muscles and reduces the body's sensitivity to pain, cold and heat. Also, valine is required for maintaining the normal hydrogen metabolism in the body [22].

In the composition of substitute amino acids, the plant-based milk analogue from fenugreek seeds is dominated by glutamine acid $(0.92 \mathrm{~g} / 100 \mathrm{~g})$, aspartic acid $(0,84 \mathrm{~g} / 100 \mathrm{~g})$, and arginine $(0,64 \mathrm{~g} / 100 \mathrm{~g})$. Aspartic acid has many important biological functions in the human body: it is involved in the synthesis of immunoglobulins, it accelerates rehabilitation from the tiredness and increases the working capacity, helps the body uptake complex carbohydrates and involve their metabolites in the formation of DNA and RNA. Also, it is capable to deactivate ammonium through connecting its molecules, thus transforming ammonium into asparagine that is safe for the body. Most importantly, aspartic acid transforms ammonium into urea, to remove it from the body. Apart from this, it helps the liver remove from the body residual components of chemical substances and medical drugs [22].

Glutamine acid is a part of many biologically active substances; it underlies the synthesis of ornithine and proline.
Like aspartic acid, it decomposes ammonium with forming non-toxic glutamine, it is involved in protein and carbohydrate metabolism, it stimulates oxidation processes, helps decompose and remove ammonium from the body, enhances the body's immunity to hypoxia. Also, it stimulates the synthesis of acetylcholine and Adenosine triphosphate, the transmission of potassium ions, it has an important role in the function of skeleton muscles. Glutamine acid belongs to neurotransmission amino acids, stimulating the transmission of excitement in the synapses of nervous system [21].

Arginine is a conditionally irreplaceable amino acid, synthesized in the body in insufficient quantities. Its deficit causes quick occurrences of pathological processes. Arginine is involved in the synthesis of proteins and many biologically important molecules, being a composite element required for the synthesis. But one of its foremost functions is the ability to be a substrate for the synthesis of nitric oxide. Arginine is involved in metabolism processes: it activates carbohydrate and lipid metabolism, reduces the adipose tissue and increases the muscle one. L-arginine has a special effect for the cardiovascular system, being able to regulate the vascular tone (the muscular wall of blood vessels). Also, its anti-thrombus and anti-sclerosis effects, hypotensive and anti-ischemic effects are well-known. So, the universality of this amino acid and its specific effects for the human body confirms the need to maintain its constant concentration in the human body. It should be noted that arginine and glutamine acids are often used in medical treatment of liver diseases, which is also necessary for patients with sugar diabetes [21, 23].

It is known that the completeness of proteins depends on not only the amino acid content, but on their ratio, balance, absorption rate etc. A more reliable assessment of the biological value of protein can be ensured by the method of amino acid score, which is the most applicable one in the present-day practice $[22,24]$. An analysis of the biological value of the plant-based milk analogue from fenugreek seeds was made by computing the amino acid score of proteins and comparing it the reference protein of FAO/WHO [25]. The amino acid score was computed with including the sum of amino acids containing sulfur and aromatic amino acids, because methionine in the body is transformed into cyctine, and phenylalanine - into thyrosine. Results of the computation are given in Table 2 .

Table 2. The amino acid score of the plant-based milk analogue from fenugreek seeds.

\begin{tabular}{llll}
\hline \multirow{2}{*}{ Amino acid name } & FAO/WHO scale, & Amino acid score, \% & Control \\
\cline { 2 - 4 } & g/100g of protein & Plant-based milk analogue from fenugreek seeds & 5,6 \\
\hline Lysine & 5,5 & 4,7 & 5,5 \\
Threonine & 4 & 7,5 & 7,4 \\
Methionine + cystine & 3,5 & 3,4 & 18,2 \\
Valine & 5 & 8,6 & 7,3 \\
Isoleucine & 4 & 8,3 & 6,6 \\
Leucine & 7 & 9 & 6 \\
Phenylalanine + tyrosine & 6 & 4,8 & 4 \\
Tryptophan & 1 & 2 & \\
\hline
\end{tabular}

From the above given data it can be concluded that the 
fenugreek seeds is leucine, and limiting one is tryptophan. In the control product, valine is the dominant amino acid, and tryptophan is the limiting one, just like in the tested drink.

The amino acid score shows the limit on the use of the protein's nitrogen for plastic purposes. A surplus of other amino acids contained in a protein can be used as a source of non-specific nitrogen or for satisfying the energy needs of the body. However, because the amino acid score cannot give a full idea of the biological value of a product, the degree of protein use were assessed by computing the coefficient of amino acid rate difference (CARD) and the biological value (BV) (Table 3).

Table 3. The biological value of proteins of the plant-based milk analogue from fenugreek seeds.

\begin{tabular}{|c|c|c|c|c|c|}
\hline \multirow{2}{*}{ Amino acid name } & \multirow{2}{*}{$\begin{array}{l}\text { FAO/WHO scale, } \\
\text { g/100g of protein }\end{array}$} & \multicolumn{2}{|c|}{ Plant-based milk analogue from fenugreek seeds } & \multicolumn{2}{|l|}{ Control } \\
\hline & & AAS, $\%$ & SDAAS - & AAS, $\%$ & DDAAS - \\
\hline Lysine & 5,5 & 4,7 & 2,7 & 5,6 & 1,6 \\
\hline Threonine & 4 & 7,5 & 5,5 & 5,5 & 1,5 \\
\hline Methionine + cystine & 3,5 & 3,4 & 1,4 & 7,4 & 3,4 \\
\hline Valine & 5 & 8,6 & 6,6 & 18,2 & 14,2 \\
\hline Isoleucine & 4 & 8,3 & 6,3 & 7,3 & 3,3 \\
\hline Leucine & 7 & 9 & 7 & 6,6 & 2,6 \\
\hline Tryptophan & 1 & 2 & 0 & 4 & 0 \\
\hline$\sum \triangle \mathrm{DAAS}$ & & & 32,3 & & 28,6 \\
\hline CARD & & & 4,04 & & 3,6 \\
\hline Biological value & & & 96 & & 96,4 \\
\hline
\end{tabular}

From the above given data it can be concluded that the developed plant-based milk analogue from fenugreek seeds has a high biological value, considering that for the reference protein it equals $100 \%$. BV for the tested drink and the control product is nearly the same (96 and 96.43, respectively), which is important when it is born in mind that by now only soya has been regarded as the best compliant with proteins of the traditional milk by protein content and amino acid composition. The derived data confirm the hypothesis about the applicability of fenugreek seeds as an input in the production of plant-based analogues of milk.

Plant-based analogues of milk should be elaborated with due consideration to not only the chemical composition of the main input material and its biological effect, but to their ability to satisfy the needs of potential consumers in certain kinds of nutrients, proteins, lipids and carbohydrates in particular (Table 4).

Table 4. The content of nutrients in the plant-based milk analogue from fenugreek seeds.

\begin{tabular}{|c|c|c|c|c|}
\hline \multirow{2}{*}{ Products } & \multicolumn{4}{|c|}{ Nutrients, $g / 100 g$} \\
\hline & Proteins & Lipids & Carbohydrates & Dietary fibers \\
\hline Plant-based milk analogue from fenugreek seeds & 2,3 & 1,2 & 3,5 & 2,9 \\
\hline Control & 3,0 & 1,8 & 3,0 & 0,5 \\
\hline
\end{tabular}

The above given data show that the control drink exceeds the milk analog from fenugreek seeds by amount of protein and lipids, which conforms to the data on the content of key nutrients in plant-based inputs. It should be noted, however, that compared with the protein content in milk analogues made of other input materials the drink made of fenugreek seeds is the second best compliant with the traditional milk after the soya drink. The developed product exceeds the soya control by protein content. By content of dietary fibers the developed drink exceeds essentially the control one (2.9 and $0.5 \mathrm{~g} / 100 \mathrm{~g}$, respectively). The derived data confirm the hypothesis on the usefulness of the product consumption in mass-scale consumption and by patients with sugar diabetes and intolerance of milk protein.

The derived data on the content of key nutrients in the plant-based milk analogue from fenugreek seeds were used in computing its energy value and the shares of nutrients in the total energy value (Table 5).

Table 5. The energy value of the plant-based milk analogue from fenugreek seeds.

\begin{tabular}{lllll}
\hline \multirow{2}{*}{ Products } & \multirow{2}{*}{ Energy value, $k$ cal } & \multicolumn{2}{c}{ The share of nutrients in the total energy value, \% } \\
\cline { 2 - 4 } & & Proteins & Lipids & \multicolumn{2}{c}{ Carbo-hydrates } \\
\hline Plant-based milk analogue from fenugreek seeds & 36,7 & 32,9 & 17,1 & 50,0 \\
Control & 39,4 & 38,5 & 23,1 & 38,5 \\
\hline
\end{tabular}

Analysis of the results shows that compared with the control product, the tested drink has a slightly smaller calorific capacity due to the reduced content of lipids. Basically, the low calorific capacity makes it possible to use the plant-based milk analogue from fenugreek seeds to diversify the rations for dietary and therapeutic feeding. This can be easily done due to a relatively high content of carbohydrates mostly consisting of indissoluble dietary fibers, which helps improve metabolism and reduce the level of glucose and cholesterol in blood.

\section{Discussion}

Most part of works devoted to testing of plant-based milk 
analogs does not contain evidence that fenugreek seeds have ever been used in making of these products. Also, researchers tend to overlook the issues of fenugreek effects for the dietary and biological value of food products containing it. Alternative plant-based inputs for the production of milk analogues, including an analysis of their dietary and biological value, are explored in [26], but fenugreek seeds are not considered as a potential input material for making this group of products. Issues of forming nutrient properties of plant-based milk analogues are highlighted in [27], but literary evidence about developments of plant-based milk analogues using fenugreek seeds are not given. The chemical composition of fenugreek and some of its biologically valuable substances are described in [28]. The author argues that dietary supplements and products containing fenugreek as an enriching agent can be found on the market, but there is no research evidence of the nutritional properties of food products made thereof or the production of a plant-based milk analogue from fenugreek seeds. Our research differs from the above mentioned works, as fenugreek seeds are looked at in it from a new perspective: as a potential input material for the production of a plant-based milk analogue, which biological value rests on solid research evidence.

Many works are devoted to testing of chemical composition of fenugreek seeds and investigating effects of its essential biological substances for the human body. In [29] it is found that steroid saponins have very a important biological role: they stimulate the synthesis of hormones, expose hemolytic, hypocholesterolemic, anti-tumor, fungicide and other types of biological activity. Author of the work [30] argues that anti-diabetes properties of this plant are due to the system effect of galactomannans and 4-hydroxyisoleucine. Author [31] says that mucous substances of galactomannans of fenugreek seeds cause the stomach protection effect and used for medical treatment of pancreatitis. Research [32] aims to identify the impact of fenugreek seeds on the course of sugar diabetes. The work [33] demonstrates the effectiveness of soluble dietary fibers (including galactomannans) in medical treatment of sugar diabetes, with elaborating on the mechanisms by which dietary food fibers can improve glucose homeostasis in persons suffering from diabetes. But neither of the above mentioned works contains an evidence of the biological value of fenugreek seeds and effects of its biologically active substances for the formation of organoleptic and physical-chemical characteristics of food products made thereof.

There are some works devoted to the comparison of the chemical composition of the traditional milk and its plant-based analogues. Issues of the energy value and the content of important chemical substances in the traditional milk and plant-based its analogues are analyzed in [34]. The author points out to the essential difference between the dietary profile of the traditional milk and its plant-based analogues, with emphasizing that this difference is caused by input materials and methods for their processing. Drinks made of soya, almond, flax, quinoa etc. are explored in [34], but nothing is said about fenugreek seeds.
An analysis of the chemical composition of various kinds of the traditional milk by amount of fat and type of heat processing, and their comparison with plant-based analogues by dietary and energy value are given in [35]. Besides this, the author investigates the amino acid composition of cow milk, serum and plant-based milk analogues. However, data about fenugreek seeds and their applicability for the production of a plant-based analogue of milk are not found. The protein content and the amino acid composition in the commercial samples of isolates of plant-based protein is explored and compared with isolates of animal-based protein in [36].

A weak side of the above works is that research is made on limited data about input materials, with missing data on fenugreek seeds. Besides that, [34] does not contain a description of the amino acid composition of research objects.

Research of the amino acid composition of fenugreek seeds can also be found. The isolate of protein extracted from fenugreek seeds, namely its amino acid composition, and thermal and functional properties, is explored in [37], with emphasis made on extraction optimization technologies. An analysis of metadata on fenugreek properties and applications, with investigating its amino acid composition in comparison with other plants, is contained in [38]. Advantages of using fenugreek seeds in food and pharmaceutical industries are analyzed in [39]. A large part of this work is devoted to investigation of the amino acid composition and content of protein in fenugreek seeds. However, the above works do not contain either an analysis of food products made of fenugreek seeds or an investigation of their amino acid composition and the biological value of protein.

Basically, the advantage of our research compared with the existing works is that the evidence from our tests of the dietary and energy value, and the amino acid composition confirms that fenugreek seeds can well be used in the production of plant-based milk analogues. The results confirm rather high protein content in the developed product. It is an important finding bearing in mind that the plant which is now believed to be the closest one to the traditional milk by protein and amino acid content is soya. So, our evidence confirms that fenugreek seeds can be regarded as a plant-based source of protein and be used to expand the assortment of food products made of fenugreek seeds for people with special needs (in particular for patients with sugar diabetes and intolerance to milk protein), as well as for a broader range of consumers.

Further research needs to be focused on the problems of fenugreek combinations with other sources of protein and their impact on the amino acid composition and the amount of protein in food products, analogues of dairy products from fenugreek seeds in particular, including sour cream, cheese, yogurts, ice-cream etc. Fermentation processes and their effects for the dietary and biological value of proteins of the milk analogue made of fenugreek seeds is another relevant topic for research. It will enable to make the tested plant-based drink more compliant with the traditional milk by chemical composition, which will have positive implications for launching industrial production of milk analogue from fenugreek seeds, to meet consumer needs. 


\section{Conclusion}

The analogue of milk from fenugreek seeds contains quite large quantities of irreplaceable amino acids, of which the largest share is with leucine and valine that have important biological effects. It is found that the composition of amino acids in the analogue of milk from fenugreek seeds is dominated by glutamine and aspartic acid, and arginine.

Results of the amino acid computation show that the dominant amino acid in the milk analogue from fenugreek seeds is leucine, and the limiting one is tryptophan. In the control product valine is the dominant amino acid, and tryptophan is the limiting one, just like is the tested drink.

It is found that the biological value of proteins contained in the milk analogue from fenugreek seeds makes $95.96 \%$, which is very close to the biological value of control (96.43\%); this evidence is positive considering that soya is believed to be best compliant with the traditional milk by amino acid composition. Results of this test confirm the hypothesis that fenugreek seeds are applicable as an input material for the production of plant-based milk analogues.

Considering the balanced amino acid composition of the milk analogue from fenugreek seeds and the high biological value of its protein, fenugreek seeds can be effective input material for the production of milk analogues, to meet consumer needs.

\section{References}

[1] Dubinina, A., Lenert, S., and Popova, T. (2015). Analysis of amino acid composition and biological value of buckwheat protein of different varieties [in Ukrainian: Аналіз амінокислотного складу та біологічної цінності білка крупи із гречки різних сортів]. Food, light and chemical industry technologies, 4/4 (24): 55-61.

[2] FAO/WHO (2013). Dietary protein quality evaluation in human nutrition. Report of an FAO Expert Consultation FAO Food and nutrition, 92, Rome, Italy.

[3] Babich, A., and Poberezhnaya, A. A. (2008). World resources of vegetable protein. Breeding and seed production, 96: 215-222.

[4] Kamyl, A.-B., Prudnykov, V., Shapovalov, S. et al. (2013). Assessment of the biological usefulness of milk proteins [in Russian: Оценка биологической полноценности белков молока]. Science and technology bulletin, 109 (2): 57-64.

[5] Morelli, L., Amrani, N., Goulet, O., Lukito, W. (2019). Lactose Intolerance: Clinical Symptoms, Diagnosis and Treatment. Global Diabetes Open Access Journal, 1.1. [Online]. Available at: https://www.yogurtinnutrition.com/wp-content/uploads/2019/ 09/2019 lactose-intolerance-clinical-symptoms-diagnosis-and -treatment-yini-wgo.pdf [Accessed: 16.04.2020].

[6] Yarmilko, N. (2019). Milk protein allergy VS lactose intolerance - what bothers you? [in Russian: Аллергия на белки молока VS непереносимость лактозы - что беспокоит именно вас?]. [Online]. Available at: https://allergy.org.ua/ru/allerhyia-na-belky-moloka-vs-neperen osymost-laktozy-chto-bespokoyt-ymenno-vas/ [Accessed:
16.04.2020].

[7] Carvalho, N. F., Kenney, R. D., Carrington, P. H. et al. (2001). Severe nutritional deficiencies in toddlers resulting from health food milk alternatives. Pediatrics, 107 (4): E46.

[8] Gueguen, L., and Pointillart, A. (2000). The bioavailability of dietary calcium. Journal of the American College of Nutrition, 19 (2): 119-136.

[9] Koshelnyk A. (2020). Production of plant-based milk analogue from fenugreek seeds. [in Ukrainian: Виробництво аналогу молока 3 насіння пажитнику грецького]. In: Innovative technologies and improvement of food production efficiency: proceedings of the All-Ukrainian scientific-practical conference in absentia. Uman National University of Horticulture, April 7. Uman: Department of Food Technology, Uman National University of Horticulture, pp. 105-108.

[10] Srinivasan, K. (2006). Fenugreek (Trigonella foenum-graecum): A review of health beneficial physiological effect. Food reviews international, 22: 203-224.

[11] James, R. (1976). Instruction manual single-column amino acid analys. California, USA: Durrum. Chemical Corporation Printed.

[12] KozarenkO, T., Zuev, S., and Muliar, N. (1981). Ion-Exchange Chromatography of Amino Acids (Theoretical Background and Practice) [in Russian: Ионообменная хроматография аминокислот (Теоретические основы и практика)]. Novosibirsk: Nauka.

[13] Ovchynnykova, YU. (1974). New methods for the analysis of amino acids, peptides and proteins [in Russian: Новые методы анализа аминокислот, пептидов и белков]. Moscow: Mir.

[14] Kozarenko, T. (1975). Ion-exchange chromatography of amino acids [in Russian: Ионообменная хроматография аминокислот]. Novosibirsk: Nauka.

[15] Rohov, Y., Antypova, N., and Dunchenko, N. (2007). Food Chemistry [in Russian: Химия Пищи]. Moscow: KolosS.

[16] Tolstohuzov, V. B. (1987). New forms of protein food (Technological problems and production prospects) [in Russian: Новые формы белковой пищи (Технологические проблемы и перспективы производства)]. Moscow: Agropromizdat.

[17] State standard of Ukraine 7458: 2013 (2015). Protein products of plant origin. Cakes and meal. Method for determining fat content (in Ukrainian: Продукти білкові рослинного походження. Макухи та шроти. Метод визначання вмісту жиру). Kyiv: Ministry of economic development of Ukraine.

[18] ISO 20483: 2013 (2013). Cereals and pulses. Determination of the nitrogen content and calculation of the crude protein content. Kjeldahl method. - This reference [18] is correctly written. 2013 is year of entry into force of this document, it is indicated in the name of the source and it is indicated separately in parentheses as the year of creation of this source.

[19] ISO 22662: 2007 [IDF 198: 2007] (2007). Milk and milk products - Determination of lactose content by high-performance liquid chromatography (Reference method).

[20] Fyodorova R. A. (2015). Food Chemistry (in Ukrainian: Харчова хімія). St. Petersburg: Universitet ITMO. 
[21] Gorbatova, K. (2001). Biochemistry of milk and dairy products [in Russian: Биохимия молока и молочных продуктов]. Moscow: GIORD.

[22] Hulich M., Motuzka YU., Antiushko D. (2014). Amino acid composition of products for enteral nutrition [in Ukrainian: Амінокислотний склад продуктів для ентерального харчування]. Commodities and markets, 1: 60-66.

[23] Skurykhyn, Y., and Nechaev, A. (1991). Everything about food from the point of view of a chemist [in Russian: Bce о пище с точки зрения химика]. Moscow: Vysshaya shkola.

[24] Lypatov, N., and Tarasov, K. (1985). Reconstituted milk [in Russian: Восстановленное молоко]. Moscow: Agropromizdat.

[25] Kraievska, S. P., Stetsenko, N. O., and Bandurenko, H. M. (2018). Flax Seed Protein Quality Assessment by DIAAS [in Ukrainian: Оцінювання якості білка насіння льону методом DIAAS]. Cereal products and compound feeds, 18, I. 3: 10-15.

[26] Elsevier.com (2017). Taste and health affect consumer choices for milk and nondairy beverages. [Online]. Available at: https://www.elsevier.com/about/press-releases/research-and-jo urnals/taste-and-health-affect-consumer-choices-for-milk-andnondairy-beverages [Accessed: 13.04.2020].

[27] Haas, R., Schnepps, A., Pichler, A. et al. (2019). Cow Milk versus Plant-Based Milk Substitutes: A Comparison of Product Image and Motivational Structure of Consumption. Sustainability, 11: 5046 .

[28] Wani, S. A., and Kumar, P. (2018). Fenugreek: A review on its nutraceutical properties and utilization in various food products Journal of the Saudi Society of Agricultural Sciences, 17: 97-106.

[29] Benichou, A. (1999). Steroid-saponins from fenugreek seeds: extraction, purification, and surface properties. Journal of Dispersion Science and Technology, 20: 581-605.

[30] Broca, C. (2000). 4-Hydroxyisoleucine: Effects of synthetic and natural analogues on insulin secretionEuropean Journal of Pharmacology, 390: 339-345.

[31] Dogaru, M. T. (2003). The gastroprotective effect of the poliholosides from the mucilage obtained from Trigonella foenum-graecum in experimental ulcer in rats. Farmacia, 51: 20-27.

[32] Kochhar, A., and Nagi, M. (2005). Effect of supplementation of traditional medicinal plants on blood glucose in non-insulin-dependent diabetics: A pilot study. Journal of Medicinal Food, 8: 545-549.

[33] Mccarty, M. F. (2002). Glucomannan minimizes the postprandial insulin surge: a potential adjuvant for hepatothermic therapy. Medical Hypotheses, 58: 487-490.

[34] Mäkinen, O., Wanhalinna, V., Zannini, E., Arendt, E. K. (2015). Foods for Special Dietary Needs: Non-Dairy Plant Based Milk Substitutes and Fermented Dairy Type Products. Critical Reviews in Food Science and Nutrition, [Online]. Available at: https://www.researchgate.net/publication/270656365_Foods_f or_Special_Dietary_Needs_Non-Dairy_Plant_Based_Milk_Su bstitutes_and_Fermented_Dairy_Type_Products [Äccessed: 13.04.2020].

[35] Mcclements, D. J., and Newman, E. (2019). Plant-based Milks: A Review of the Science Underpinning Their Design, Fabrication, and Performance. Comprehensive Reviews in Food Science and Food Safety. [Online]. Available at: https://onlinelibrary.wiley.com/doi/full/10.1111/1541-4337.12 505 [Accessed: 13.04.2020].

[36] Gorissen, S. H. M., Crombag, J. J. R., Senden, J. M. G. et al. (2018). Protein content and amino acid composition of commercially available plant-based protein isolates. Amino Acids, 50 (12): 1685-1695.

[37] Feyzi, S, Varidi, M., Zare, F. et al. (2015). Fenugreek (Trigonella foenum graecum) seed protein isolate: extraction optimization, amino acid composition, thermo and functional properties. J Sci Food Agric, 95 (15): 3165-76.

[38] Żuk-Gołaszewska K., Wierzbowska J. (2017). Fenugreek: productivity, nutritional value and uses. Journal of Elementology, 22 (3): 1067-1080.

[39] Khorshidian, N., Asli, M. Y., Arab, M. et al. (2015). Fenugreek: potential applications as a functional food and nutraceutical. Nutrition and Food Sciences Research, 3: 5-16. 